\title{
A Construção do Concílio Vaticano II: intuições germinais do Papa João XXIII em vista de um evento renovador
}

\author{
Construction of the Second Vatican Council: germinal intuitions of Pope John \\ XXIII in view of a renewal event
}

João Décio Passos*

\begin{abstract}
Resumo
O Concílio Vaticano II foi construído dentro de uma tradição solidamente constituída na Igreja católica. Todos os Concílios foram realizados dentro dos parâmetros tradicionais e legais da Igreja. A pergunta pela condição de possibilidade de um Concílio renovador no âmbito dessa tradição se mostra relevante. 0 Vaticano II é o resultado de uma negociação entre renovação e preservação. O Papa João XXIII coordenou pessoalmente a construção da legitimidade do novo evento, seguindo passos que podem ser recuperados no decorrer das fases preparatórias da grande assembleia. A leitura desse processo a partir de parâmetros sociológicos pode elucidar sua plausibilidade dentro da tradição e da organização burocrática da Igreja. 0 Papa João iniciou habilmente um processo de renovação da Igreja, inaugurando uma nova fase na longa tradição católica. Na condição de Papa soube plantar a ideia de um evento renovador, em nome de uma inspiração divina e contando com a participação do conjunto dos bispos da Igreja.
\end{abstract}

Palavras-chave: Construção social, João XXIII, Legitimidade, Renovação e Vaticano II.

\begin{abstract}
The Second Vatican Council was built within a solidly constituted tradition in the Catholic Church. All councils were held within the traditional and legal parameters of the Church. The question about the condition of possibility of a renewal Council under this tradition shows relevant. The Vatican II is the result of a negotiation between renewal and preservation. Pope John XXIII personally coordinated the construction of the legitimacy of the new event, following steps which may be rescued during the preparatory stages of the great assembly. The reading of this process from sociological parameters may elucidate its plausibility within the tradition and the Church's bureaucratic organization. Pope John started ably a church renewal process, opening a new phase in the long Catholic tradition. Under his Pope condition, he knew how to seed the idea of a revamping event in the name of a divine inspiration and with the set of bishops' participation of the Church.
\end{abstract}

Keywords: Social construction, John XXIII, Legitimacy, Renewal and Vatican II

\footnotetext{
Artigo recebido em 05 de março de 2016 e aprovado em 14 de setembro de 2016.

* Doutorado em Ciências Sociais pela Pontifícia Universidade Católica de São Paulo, Brasil (2001). Livre Docência pela Pontifícia Univ. Católica de SP, Brasil (2008). Professor doutor do Instituto Teológico São Paulo, Brasil. País de Origem: Brasil. E-mail: jdpassos@pucsp.br
}

Horizonte, Belo Horizonte, v. 14, n. 43, p. 1012-1038, jul./set. 2016 - ISSN 2175-5841 


\section{Introdução}

O anúncio de um novo Concílio feito por João XXIII, em 25 de janeiro de 1959, foi totalmente inédito para os fiéis e para a hierarquia católica, bem como para os organismos e membros da Cúria Romana. O mundo foi também surpreendido pela notícia que ganhou imediatamente as principais mídias. Ninguém supunha que o Papa idoso conceberia essa ideia e, menos ainda, de maneira tão súbita. Os cardeais foram tomados de surpresa ainda maior por não serem avisados previamente da decisão, sabendo das rotinas institucionais do papado sempre sintonizadas diretamente às assessorias curiais e a eles próprios, na condição de colaboradores diretos. Na verdade, também para o Papa tratava-se de algo que brotara inesperadamente; declara que o surgimento súbito da ideia teria sido por inspiração divina: "flor de inesperada primavera", "novo pentecostes" e "nova epifania", são as metáforas que foram utilizadas para expressar a decisão sem grandes reflexões, porém fundada em um dom sobrenatural.

De fato, a ideia do Vaticano II foi construída com eficiência por seu idealizador. Tratava-se de uma criação inusitada que tomou sua configuração no âmbito da Igreja católica estabelecida em sua rotina burocrática e estável em sua tradição. Para que se tornasse viável o propósito de um novo Concílio com objetivos reformadores foi, sem dúvidas, fundamental a figura de João XXIII que, por um lado, nada mais fez que exercer sua prerrogativa de convocar Concílio e de contar para tanto com a fidelidade dos bispos, e, por outro, lançou mão de estratégias políticas perspicazes, sem as quais o novo evento não vingaria e muito menos tomaria os rumos que tomou. A leitura sociopolítica do processo conciliar não exclui as leituras de fé sobre o seu percurso, coisa que o próprio João XXIII não cessa de expressar ao tratar das motivações primeiras do evento e de sua origem em uma inspiração divina. Contudo, é necessário perceber no desenrolar do processo o jogo real de forças com as quais se envolvia o Pontífice, sobretudo com as figuras institucionais de sua Cúria. Por vezes, o Papa bondoso pode parecer, de fato, um carismático ingênuo que na mais pura fé convoca o grande evento sem 
pensar em suas consequências mais imediatas e nos opositores que estavam dentro de sua própria casa. A leitura espiritual feita pelo próprio Papa não exclui as opções políticas que tomou desde o primeiro anúncio até suas últimas decisões antes de sua morte.

A ideia do novo Concílio foi socialmente construída pelo Papa João e assumida em seu propósito original por Paulo VI e pelos padres conciliares em sua maioria, a partir da segunda Sessão em 1963. Na ocasião, já havia um relativo consenso construído na mente dos padres conciliares a respeito do evento. Muito embora o processo conciliar conheça tensões, esse consenso será aprimorado a partir de um conhecimento e de um valor que já possuíam e que haviam emanado do coração e da boca do Papa. É possível cogitar que sem o carisma de João XXIII o Concílio não tivesse acontecido naquele momento e menos ainda como aconteceu. Para tanto, era necessária a força carismática de um líder que tivesse legitimidade suficiente para romper com a inércia da instituição e agregar a ele o novo. Para essa função, o Papa João se mostra como a pessoa certa que soube tirar proveito das possibilidades na hora certa. A leitura de fé desse processo é, sem dúvidas, a mais tentadora de ser feita: o Espírito conduziu a Igreja naquele momento histórico! Contudo, é necessário verificar nos fatos e no processo o rumo politicamente construído e que vai tornando o projeto de aggiornamento legítimo e plausível para a Igreja. Estava em jogo a construção de uma nova tradição no seio de uma outra antiga e era necessário haurir dessa os elementos fundadores daquela (HOBSBAWM, 2002, p. 12-13). Esse é o percurso feito por João XXIII a cada passo que dava na construção progressiva da ideia do novo Concílio.

Portanto, falar em construção da ideia do Concílio significa examinar o jogo concreto das possibilidades históricas que envolvem sujeitos, mentalidades e estratégias em uma determinada conjuntura institucional. Significa, portanto, evitar as leituras do acaso ou da predeterminação sobrenatural que dispensam o exame das variáveis reais que naquele momento estiveram em jogo. A presente reflexão afirma que a ideia de um novo Concílio, como um evento original e 
renovador, foi sendo construída por João XXIII nos tempos de sua preparação. Esse processo pode ser lido analiticamente, sobretudo com a ajuda da teoria da construção social da realidade formulada por Berger e Luckmann. Para tanto, serão examinadas as declarações feitas e as decisões tomadas por João XXIII nas fases preparatórias do Concílio, tendo como fonte as crônicas conciliares elaboradas por Boaventura Kloppenburg1, na ocasião perito conciliar. O fato é que na abertura do grande evento o Papa e muitos de seus pares diretos já contavam com um universo simbólico já bastante completo sobre o que ele deveria ser. É sobre essa construção primeira que o Vaticano II concluído quatro anos depois se assenta em suas coordenadas principais.

\section{Um evento inusitado para uma instituição estável}

Havia apenas três meses da eleição do cardeal ancião para o papado. Tratava-se, como pensavam, de um Papa de transição. Os pontificados longos dos dois Papas anteriores pareciam ter deixado uma Igreja mais do que nunca estável, na linha implantada desde o Vaticano I. O Papa era o centro visível do poder hierárquico, epicentro em torno do qual gravitavam os poderes episcopais locais, ponto de origem das decisões do Magistério, detentor de prerrogativas infalíveis, pastor universal etc. A Igreja, embora abalada pelas duas grandes guerras e sempre mais acuada pelas ciências modernas e por uma cultura secularizada, não expressava publicamente sinais de crise, menos ainda de crise institucional que exigisse qualquer guinada em seu rumo. A rotina institucional seguia seu curso regular, coordenada pelo sucessor de Pedro, estruturada pelo Direito Canônico, amparada por uma eclesiologia do corpo hierárquico, administrada pelos Dicastérios curiais, assegurada em seus territórios do Estado do Vaticano, bem relacionada diplomaticamente com boa parte dos Estados modernos, unificada por praticas litúrgicas, catequéticas e devocionais universais, defendida na sociedade e na política pelos leigos por meio da Ação Católica. Uma instituição consolidada em

\footnotetext{
${ }^{1}$ Publicação da Editora Vozes em 5 volumes sob o título comum Concilio Vaticano Il abrangendo a fase preparatória (Vol. I, 1962) e as
} quatro sessões do Concílio sucessivamente (Vol. II, 1963, Vol. III, 1964, Vol. IV, 1965 e Vol. VI, 1966).

Horizonte, Belo Horizonte, v. 14, n. 43, p. 1012-1038, jul./set. 2016 - ISSN 2175-5841 
sua totalidade e por si mesma legítima à qual não havia nada a acrescentar (BERGER \& LUCKMANN, 1985, p. 95-126).

Ademais, o novo Papa não havia sido eleito imbuído de qualquer tarefa reformadora, como muitas vezes ocorre nos conclaves. Ao contrário, certamente todos supunham uma serena continuidade na vida da Igreja, nos processos de funcionamento eclesiástico, na preservação da tradição e da teologia escolástica oficial e nos padrões de relacionamento político e social da Igreja com a sociedade e a política modernas. É verdade que o mundo havia desabado no decorrer do século $\mathrm{XX}$, bem como se transformado por completo em sua configuração geopolítica e em seus aparatos tecnológicos. Porém, essas mudanças haviam contribuído para que a Igreja afirmasse com maior convicção a sua estabilidade como mãe e mestra da humanidade, abalada em suas bases tradicionais e, sobretudo, perante a secularização e o ateísmo que cresciam e se institucionalizavam, sobretudo nos regimes socialistas em franca expansão desde a primeira guerra mundial.

Com esse imaginário predominante de estabilidade eclesial, ninguém imaginaria tamanha ousadia da parte do Papa recém-eleito naquele momento. A convocação de um Concílio era quase uma falta de juízo, por se tratar de uma iniciativa desnecessária para a Igreja. Pio XII já havia pensado em convocá-lo e não havia levado adiante a proposta, não obstante seu longo pontificado, sua maestria diplomática e sua reconhecida envergadura intelectual (KLOPPENBURG, 1962, p. 9). A longa era de Pio XII, conectada histórica e eclesialmente à era dos "papas pios", marcada pela centralidade do poder papal e pela estabilidade institucional e doutrinal, parecia preservar a Igreja católica em uma muralha bem estabelecida que por si mesma dispensaria qualquer revisão eclesial e eclesiástica. Ademais, o Vaticano I, mesmo que inconcluso, dera ao Sumo Pontífice tal autoridade doutrinal que levava muitos a postular o fim da era dos Concílios. O Papa resumira, segundo essa visão, todas as funções que antes eram delegadas aos Concílios, ditando para toda a Igreja, por meio de sua hierarquia descendente, todas as matérias de doutrina, moral e disciplina. O anúncio de um novo Concílio foi recebido, portanto, 
com perplexidade e indiferença por parte de muitos bispos, particularmente da Cúria Romana. E para muitos era de certo modo natural que um novo Concílio só poderia ser, de fato, a conclusão do Vaticano I, abruptamente encerrado em 1870; deveria vir somente para reafirmar com vigor essa espécie de "tradição concluída” da Igreja católica (O’MALLEY, 2014, p. 46-49).

Mas, é precisamente por dentro dessa tradição estável que emerge a figura carismática de João XXIII com a proposta de um evento que, desde sua concepção no coração e na mente do velho Pastor, foi entendido inequivocamente como uma inspiração que vinha do alto. Em termos weberianos, pode-se dizer que se tratava de um poder carismático constituindo-se no seio de um poder tradicional e burocrático, lançado, por conseguinte, a todas as consequências políticas do fato (WEBER, 1997, p. 196-197; 848). As intenções do Papa em relação ao inusitado foram pouco a pouco sendo comunicadas por ele próprio, angariando entusiastas e atiçando a insegurança e resistência por parte dos tradicionalistas e dos burocratas da Igreja. Com efeito, vale aqui a pergunta política pelas condições de possibilidade de um Concílio naquele contexto eclesial de estabilidade e rotina institucional. Nenhuma heresia ameaçava a unidade da fé e nenhum reformador abalava a sua estabilidade. Qual seria, portanto, a necessidade de um Concílio? O anúncio rompia de fato com a tradição dos Concílios anteriores, convocados para resolver problemas concretos e pontuais. Mais ainda, como a ideia de um Concílio poderia encontrar sua legitimidade em uma cultura eclesial marcada pelo consenso da estabilidade? Por fim, como foi possível que o Papa ancião tenha conseguido construir um consenso em torno de sua proposta? Não há dúvidas de que, politicamente, é mais fácil compreender a reação dos que foram contra ou indiferentes ao anúncio inédito do que aqueles que propriamente aderiram de imediato ao chamado. Um Concílio tão desnecessário só poderia causar mal-estar no modelo eclesiológico e eclesiástico predominante.

Também, seria totalmente previsível que João XXIII não conseguisse autênticas adesões ao seu projeto, de forma a construir um consenso em torno de 
suas intenções de renovação da Igreja. A conservação das representações e das práticas em curso era o caminho regular que os sujeitos dirigentes da Igreja e, de modo direto, da Cúria Romana, defenderiam para qualquer assembleia mundial dos bispos. Além do mais, o fantasma do conciliarismo, embora definitivamente desfeito no V Concílio do Latrão (DENZINGER-HÜNERMANN, 2007, n. 1445), ainda habitava as mentes mais vigilantes da ortodoxia papal. Um Concílio poderia colocar em risco a centralidade do poder papal e de seu exercício estabelecido pelo Vaticano I, exercício que havia sido maximizado a ponto de transformar a infalibilidade em uma espécie de princípio geral das declarações papais. Nesse sentido, é que se poderia prever que um novo Concílio só poderia vir como conclusão do anterior, ou no máximo, como sua continuidade. No caso, os bispos viriam a Roma na condição de meros auxiliares do Papa e prontos a homologarem aquilo que previamente já devesse estar preparado pelo Papa, concretamente por sua Cúria. Não lhes restaria outra função legítima senão essa.

Consciente ou não dos limites políticos dessa conjuntura, o fato é que João XXIII deu rumos precisos às suas decisões e intencionalidades referentes ao novo Concílio, escapando desde o início dos controles dos membros da Cúria por natureza preservadores da estrutura e conservadores da tradição. A ideia de convocar a grande assembleia, mas, sobretudo, com os objetivos por ele pretendidos não vingaria nas mãos dos especialistas curiais. De fato, ao assumir a realização do Concílio como a principal pauta de seu pontificado, João XXIII estabelece uma conexão direta com o conjunto da Igreja, para além das conexões rotineiras com o aparato curial e revela-se sempre mais primus inter pares, na medida em que foca sua ação em um evento ecumênico que deveria envolver todos os bispos, a começar consultando-os sobre os rumos e pautas do mesmo. Não faltava ao Papa essa experiência e perspectiva universais. Embora estivesse ao longo de quase toda sua vida a serviço da Cúria Romana, o havia feito fora dos quadros ad intra dos Dicastérios curiais; vivenciara efetivamente suas tarefas nas periferias da Igreja, do ocidente e da cultura católica. O Concílio era, nesse sentido, 
uma continuidade dessa prática eclesial mundializada, um esforço de rever o centro a partir de uma visão descentralizada.

Para a condução desse propósito, o anúncio consistia em um primeiro passo fundamental que determinaria todos os demais a serem dados. Nessa perspectiva, o anúncio e as primeiras explicações a respeito do novo Concílio não podem ser vistos como um momento inicial isolado das demais etapas de realização do grande Sínodo, mas, ao contrário, como um modo de enunciar a novidade que muito fortemente determinou todo o processo, na medida em que possibilitou um percurso capaz de agregar as intenções e os esforços de aggiornamento para além e no próprio interior das forças conservadoras instituídas dentro da Igreja e, particularmente, dentro das estruturas oficiais da Cúria romana. O anúncio inédito, sem controles institucionais, instaurou o caminho sem volta e alimentou como fonte inspiradora o processo conciliar; foi, nesse sentido, não somente começo de um processo histórico, mas também origem permanente de um evento destinado a conduzir a Igreja a uma nova etapa.

O fato era que a ideia de um novo Concílio deveria ser construída, ou mais precisamente, socialmente construída, o que significa torná-la legítima para o conjunto da Igreja e, de modo direto, para o episcopado. Essa tarefa implicava passar da ordem subjetiva (a decisão inédita de João XXIII) para a ordem objetiva (o propósito e projeto do novo evento acolhido pelos pares), bem como articular uma tradição consolidada com o novo que buscava instaurar-se (BERGER \& LUCKMANN, 1985, p. 127-128). Essa legitimidade foi sendo construída em cada passo dado por João XXIII até a realização do grande evento, quando já se podia verificar um "universo simbólico" já concluído. Os sociólogos supracitados explicam a construção da legitimidade como um processo que segue alguns passos. O primeiro é pré-teórico, constituído de afirmações simples que enunciam o que se quer defender, o segundo já se expressa pelas primeiras explicitações teóricas e o terceiro por quadros teóricos definidos e o quarto pela constituição de "universos simbólicos", sistema completo de teorias e de normas que permitem situar os 
sujeitos dentro de um quadro de referências. Esses passos podem ser verificados analiticamente no processo de construção do novo Concílio, dentro do quadro anterior de referências institucionais (BERGER \& LUCKMANN, 1985, p. 128-142).

\section{0 primeiro anúncio}

Em reunião com Cardeais na Basílica de São Paulo Fora dos Muros, o novo Papa anuncia sua decisão de convocar um Concílio. Após constatar as dificuldades do mundo contemporâneo em viver de modo autêntico a fé em Jesus Cristo afirma possuir a "resolução decidida para a evocação de algumas formas antigas" de afirmação da doutrina e de ordenações da disciplina que, na história da Igreja, em épocas de renovação, deram frutos para a clareza do pensamento, para a unidade religiosa e para o avivamento da fé. E conclui o Pontífice:

Veneráveis irmãos e Diletos Filhos! Pronunciamos diante de vós, por certo tremendo um pouco de emoção, mas ao mesmo tempo com humilde resolução de propósito, o nome e a proposta de dupla celebração: a de um Sínodo Diocesano para a Urbe, e a de um Concílio Ecumênico para a Igreja Universal (KLOPPENBURG, 1962, p. 11-12).

O anúncio inesperado aos Cardeais não provinha de uma decisão longamente refletida e sequer de uma preparação que já estivesse em curso, mas de uma decisão bem recente que de súbito tomara o próprio Pontífice em conversa com seu Secretário de Estado; a ideia havia surgido "como flor de inesperada primavera”, explica aos assistentes da Ação Católica alguns meses depois. E mais tarde, em maio de 1962, explica a um grupo de venezianos como surgiu a ideia a partir de uma conversa com o Secretário de Estado, Cardeal Tardini:

Num momento iluminou-Nos a alma uma grande idéia, percebida precisamente naquele instante e aceita como indizível confiança no Divino mestre e saiu-Nos dos lábios uma palavra, solene e empenhadora. Nossa voz exprimiu-a então pela primeira vez: um Concílio! E para dizer a verdade, logo surgiu também o temor de haver suscitado perplexidade ou até temor [...] Mas a resposta não se fez esperar. No rosto do Cardeal manifestou-se logo uma clara emoção; seu assentimento foi imediato e exultante. Foi o primeiro sinal certo da vontade do Senhor" (In: KLOPPENBURG, 1962, p.13). 
Esse primeiro momento prima-se pelo não conceitual, mas, sobretudo por um vocabulário místico capaz de transmitir os rudimentos mais básicos da tradição católica. E será sobre esses rudimentos que os discursos posteriores de cunho mais conceitual se assentarão e serão incorporados à tradição (BERGER \& LUCKMANN, 1985, p. 129).

O Cardeal Montini, futuro Papa Paulo VI, conhecedor profundo da cultura curial, observou que a surpresa pelo anúncio do novo Concílio advinha também dos que têm conhecimento da origem regular dos atos pontifícios, sempre planejados com especialistas dos órgãos da Cúria. Afirma que

enquanto nos é dado saber, este anúncio, resolução de imensa importância, tem sua origem na única e personalíssima vontade do Sumo Pontífice. Ninguém lhe foi conselheiro ou colaborador. Ninguém exerceu sobre ele pressão de qualquer espécie; e ninguém lhe prometeu quaisquer resultados (Declaração à Revista Vita e Pensiero de Milão, Dezembro de 1960 (KLOPPENBURG, 1962, p. 12, nota 6).

Essa primeira fase de legitimação centrada no anúncio vai sendo sucedida por uma segunda em que a ideia do novo Concílio vai adquirindo uma primeira fundamentação teórica (teológica) e as primeiras formulações conceituais (BERGER \& LUCKMANN, 1985, p. 128-129). A convicção certa de que a realização do Concilio era vontade de Deus acompanhou João XXIII até sua morte, antes de ver concluído o grande evento. À realização do Concilio dedicou todas as suas energias, vendo nele um dom de Deus para a Igreja e para o mundo. Falando aos dirigentes da Ação Católica, em 9 de agosto de 1959, explica como surgiu a idéia do Concílio e sua importância:

O Concílio Ecumênico, por sua vez, apresenta-se como uma manifestação de excepcional e vastíssimo alcance, de catolicidade verdadeiramente mundial. O que está acontecendo confirma que o Senhor assiste, com sua santa graça, o salutar projeto. A idéia do concilio não amadureceu como fruto de prolongada consideração, senão qual flor espontânea de inesperada primavera. (KLOPPENBURG, 1962, p. 39-40).

E segue explicando a conveniência do evento para aqueles dias: "Pedro está

Horizonte, Belo Horizonte, v. 14, n. 43, p. 1012-1038, jul./set. 2016 - ISSN 2175-5841 
sempre pronto a ter fé na sua missão, em vista das possibilidades novas que os recursos, mesmo de ordem material, do progresso humano preparam para as vantagens de ordem espiritual”, E completa dizendo que

nos nossos dias, freqüentes são as reuniões de políticos, diplomatas, cientistas, industriais, de homens pertencentes às várias categorias do comércio e das profissões. [...] Por que então não poderiam reunir-se aqueles que são concordes na exaltação do fato mais memorável da história humana, isto é, a vitória da civilização na luz de Cristo?. (KLOPPENBURG, 1962, p. 39-40).

Acrescenta também as razões ecumênicas do novo Concílio, sabendo da divisão dos cristãos espalhados por todo o mundo nas áreas missionárias. A tarefa do Concílio é vista pelo Papa em duas direções. Uma primeira interna, que visa preparar a Igreja segundo os desígnios do Senhor para apresentá-la a todos sine macula e sine ruga. Em conseguida, ela dirigir-se-á a todos os que estão separados, os ortodoxos, os protestantes etc.

Vinde, vinde: este é o caminho aberto para o encontro, para o retorno; vinde tomar ou retomar o vosso lugar, que, para muitos de vós, é o de vossos antepassados. Da paz religiosa, da família cristã reconstituída, oh! que alegria, que prosperidade, mesmo de ordem cívica e social, é lícito esperar para o mundo inteiro (KLOPPENBURG, 1962, p. 39-40).

Na tradição tão rígida e teologicamente fundamentada e na burocracia bem estruturada da Igreja católica, somente a convicção da origem sobrenatural advinda do líder máximo, portanto, do âmago da própria instituição, poderia produzir frutos de renovação. Do contrário, toda novidade soaria como desnecessária, senão inconveniente ou, até mesmo, heterodoxa. Também, parece proceder que qualquer projeto enunciado aos funcionários da burocracia eclesiástica tenderia a ajustar-se de tal modo à lógica da conservação daquelas estruturas que perderia na rotina do planejamento demorado sua eficácia transformadora e seu frescor contagiante. João XXIII fez eclodir e sustentou de modo emblemático um carisma que se manteve in statu nascendi no decorrer da fase preparatória e no início dos trabalhos conciliares; foi capaz de embasar como 
raiz primeira o propósito do aggiornamento antes e durante o Concílio.

Certamente cabem aqui perguntas que permanecerão sem respostas certas e demonstração histórica. Teria o Papa seguido sua intuição de convocar o evento, convicto que estava de tratar-se de uma inspiração divina, sem intenções estratégicas de reservar para si a construção da ideia básica do novo Concílio, longe dos membros curiais? Ou, seguiu sua intuição como uma missão pessoal, em nome de sua autoridade de Papa, responsável primeiro de convocar e conduzir o Concílio? Ou, ainda, uma terceira hipótese: a consciência política das dificuldades que encontraria dentro da burocracia curial de levar avante seu projeto o fez reservar para si a preparação primeiríssima dos trabalhos? João XXIII trazia em seu perfil pessoal e em seu currículo as habilidades que permitem afirmar as três hipóteses como prováveis. Homem de espiritualidade profunda e simples e convicto da missão para a qual fora chamado desde a sua tenra infância ainda na condição de vocacionado e seminarista, como revela seu Diário (1964). Não vacila sobre sua missão e no diálogo consigo mesmo vai construindo sua história pessoal nas diversas etapas de sua vida. Não é difícil imaginar que sua convicção a respeito do Concílio tenha surgido de suas personalíssimas vontade e intuição, creditando tão somente a Deus a condução dos trabalhos, de modo a dispensar assessorias oficiais dos Dicastérios da Cúria. Também merece observar que o Papa de idade avançada vinha de uma longa experiência que poderia defini-lo como um sujeito eclesiástico ao mesmo tempo insider e outsider às instituições curiais. Seus trabalhos pastoral-diplomáticos no oriente, como Visitador Apostólico na Bulgária e como Delegado Apostólico na Turquia e como Núncio em Paris, lhe proporcionaram, de fato, uma experiência de acolhida do estranho e de diálogo com o mundo de fora do catolicismo, seja pelo convívio na condição de minoria com os católicos ortodoxos e com os islâmicos e com o mundo secularizado da França moderna. Não lhe era desse modo difícil agir com relativa distância da Cúria Romana, conhecedor das dificuldades de seus membros perante as renovações que desafiavam a Igreja, a partir do mundo moderno e das demais Igrejas cristãs. Ademais, o experiente diplomata sabia onde estava inserido do 
ponto de vista das políticas administrativas curiais e das possibilidades de seu ideal de Concílio ser raptado pela rotina curial e por uma visão conservadora que dispensava como perverso qualquer intento de renovação (ALBERIGO, 1996, p. 2634).

A ideia de chamar um Concílio e, mais que isso, a própria ideia que pudesse ter a respeito de um evento de objetivos reformadores não seria - como não foi bem acolhida pelos membros da Cúria Romana. Nas funções que havia ocupado durante sua vida certamente sabia disso e daí se explicaria sua determinação em semear sozinho as primeiras intuições e formulações sobre o Concílio, até o momento em que outros círculos são envolvidos nos trabalhos.

O primeiro anúncio e as primeiras explicações sobre o novo evento vão sendo feitos gradativamente como quem prepara o terreno para a plantação. Com visível convicção e entusiasmo vai lançando pouco a pouco o que deveria ser o grande Sínodo. O olhar esperançoso sobre a oportunidade e a grandiosidade do evento movem sempre seus discursos. O Concílio tomou sua primeira forma nos lábios do Papa bondoso de modo que. quando a Cúria entra em cena com todo o seu aparato para conduzir os trabalhos pré-conciliares um carisma, já havia se espalhado pela Igreja e gerado expectativas em todo o mundo. Sabe-se que o novo Papa não havia participado na condição de cardeal do projeto de Pio XII de convocar um Concílio para concluir o Vaticano I. Não se sabe se cultivava a ideia de convocar o evento entre sua eleição em 28 de outubro a 25 de janeiro quando o anuncia aos cardeais. Porém, não dá para supor unicamente uma pura intuição que de súbito lhe tenha tomado o espírito e que, logo em seguida, fosse comunicada ao Secretário Tardini e, depois, aos cardeais, sem, ao menos, a construção da convicção e da decisão pessoal. Ademais, conhecedor que era da história dos Concílios como professor de história da Igreja, sabia das dificuldades políticas da convocação de um Concílio e, ainda mais, da realização de tamanho evento naquele momento. Seja como for, o anúncio inesperado tornava o fato irreversível e só restava, então, tomar nas mãos o propósito e construí-lo em suas linhas essenciais. 
Há que ressaltar o quadro nitidamente instaurado desde a eleição do Cardeal Roncalli, no qual se deve distinguir o poder - e a autoridade - do Pontífice e poder da Cúria Romana, exercitado pelos Dicastérios, de modo precípuo pelo Santo Ofício e pela Secretaria de Estado. O poder primacial do Bispo de Roma pode ser definido como autoridade carismática tradicionalizada, conforme as regras previstas da sucessão no processo de rotinização inerente ao carisma, segundo a sociologia weberiana do poder (WEBER, 1997, p. 156-159). A Cúria Romana, por sua vez, constitui um poder tradicional burocrático que, por natureza, goza da capacidade de autofuncionamento segundo as regras pré-estabelecidas (WEBER, 1997, p.173174). Como poder carismático tradicional, o papado comporta não somente as prerrogativas da autoridade do pontífice perante os órgãos curiais, como também o arcabouço teológico e jurídico que eventualmente pode comportar figuras que se apresentam como investidas de missão reformadora. Parece ser esse o caso de João XXIII: uma figura de perfil carismático que busca em nome de um fundamento maior exercer uma missão de reformar a Igreja e, para tanto, busca formas de angariar adeptos para a sua causa. Weber explica que "carisma é a grande força revolucionária nas épocas vinculadas à tradição". Diferentemente da força transformadora da razão que opera de fora, o carisma é uma renovação que opera por dentro da tradição, nascendo da indigência ou do entusiasmo "significa uma variação da direção da consciência e da ação, com reorientação completa da consciência de todas as atitudes frente às formas de vida anteriores ou frente ao 'mundo' em geral” (WEBER, 1997, p. 196-197). Se João XXIII não nasceu da crise ou da indigência, como no caso do Papa atual, foi tomado, entretanto, por completo pelo entusiasmo em relação ao Concílio, como se pode verificar em suas colocações. E parece ser também certo que exerce seu carisma renovador como possibilidade nova que se apresenta na longa sequência de uma época ligada à tradição que se estendia desde o Vaticano I. 
Nesse sentido, o novo Concílio foi sendo gradativamente:

- Legitimado, por se tratar de uma inspiração que vinha do alto e, evidentemente, por ser lançado por quem era de direito;

- Construído, na medida em que, precisamente por não ter nascido de “prolongada reflexão" deveria ser explicado por seu autor, enquanto concepção e realização perante os fiéis, a hierarquia e a própria sociedade;

- Interiorizado pelos cristãos católicos e pela sociedade de um modo geral, tendo em vista, sobretudo, a cobertura permanente das mídias;

- Institucionalizado por ser gradativamente formatado pelo autor de direito e, posteriormente, por atos canônicos positivos;

- Assimilado em seu propósito e formato básicos pelos sujeitos eclesiais que viriam compor a grande assembleia e pela Igreja de um modo geral.

Não se trata, evidentemente, de um percurso linear de construção da ideia conciliar, mas de um processo que vai estabelecendo as condições imaginárias para a realização do evento renovador, dentro de uma instituição objetiva, estável e conservadora. João XXIII escolheu esse caminho processual, política e pedagogicamente plausível, dentro da Igreja católica e, de modo particular, dentro da cultural curial. Consciente ou não dessa viabilidade política, o Papa construiu aos poucos um caminho sem voltas, mesmo quando a Cúria traçou os rumos do evento nos trabalhos das Comissões pré-conciliares. No imaginário construído sobre o Concilio, este deveria, de fato, ser:

- Um novo Concílio e não continuidade do Vaticano I, como muitos esperavam;

- Um Concílio Ecumênico, ou seja, uma reunião de bispos representando toda a orbe católica e não para todos os cristãos, como se chegou a especular; 
- Um evento renovador no conteúdo e na forma, na medida em que se trata de refazer a Igreja para torna-la sem rugas e sem manchas perante os demais cristãos e o mundo;

- Um Concílio propositivo que não se dedicaria a questões específicas de fé e muito menos a contrapor ou condenar alguma ideia heterodoxa ou herética;

- Um evento capaz de dialogar crítica e criativamente com o mundo moderno, transformado em suas mentalidades e em seus mecanismos sociais e políticos.

O novo Concílio foi sendo legitimado, passando da fase pré-teórica para a fase teórica, quando já se podia contar com um conjunto de conceitos e regras que o delimitava, de forma a tornar-se plenamente realizado, seja do ponto de vista de um quadro cognitivo claro e dado a conhecer a todos e como norma a ser seguida pela tradição católica (BERGER \& LUCKMANN, 1985, p.128).

\section{As reverberações}

Por certo, ao menos num primeiro momento, ninguém se entusiasmou mais com a ideia do Concilio do que o próprio Papa. Dirá mais tarde em seu Diário: "As expectativas do Concilio Ecumênico Vaticano II ocupa grande parte de minhas ocupações quotidianas" (JOÃO XXIII, 1964, p. 361). O anuncio do novo Concílio foi de fato original, se comparado aos anteriores. Não foi precedido de nenhuma discussão com autoridades eclesiásticas e muito menos por qualquer articulação que visasse construir um consenso mínimo sobre seu propósito e objetivo. Com efeito, o elemento surpresa fez do evento imediatamente um fato irreversível que só restava se acolhido pelo conjunto da Igreja, se não pela força do consenso sobre a necessidade do evento, ao menos pela indiscutível autoridade papal em relação à matéria. A surpresa do anúncio produziu reações diversas dentro e fora da Igreja, perplexidade, desapontamento e indiferença. Dos 17 Cardeais presentes na 
celebração em que o Concilio foi anunciado nem todos se manifestaram oficialmente sobre o propósito. Apenas 25 cardeais se manifestaram a respeito, a maioria de modo protocolar. Os demais - 38 cardeais - não tiveram nenhuma manifestação. Era uma voz que parecia ter clamado no deserto de uma Igreja instalada na cultura da centralidade do magistério papal em matéria de doutrina, de uma cúria versada na burocracia do comando das decisões papais e de um episcopado acostumado a reproduzir a doutrina e a disciplina, sem cogitar qualquer horizonte de mudanças para a Igreja. E não faltou quem visse no propósito perigos e até a iminência de um fracasso (ALBERIGO, 1996, p. 39). É também digno de nota que o próprio órgão oficial da Santa Sé L'Osservatore romano não tenha publicado a íntegra do pronunciamento inédito do Papa, restringindo-se a notificar o comunicado oficial emitido pela Secretaria de Estado.

Além dos perplexos e dos temerosos, do ponto de vista interno da Igreja católica, o anúncio inesperado despertou perguntas sobre o objetivo do evento, assim como esperanças de parte do episcopado e de teólogos. Vale elencar uma primeira reação já orquestrada e fundamentada por parte do teólogo suíço Otto Karrer, fruto de conversas com o bispo Höfer e o jesuíta Bea. Nesse documento enviado aos bispos e teólogos se prenuncia muitas das pautas conciliares: a rejeição das proposições dogmáticas, a perspectiva ecumênica, a colegialidade episcopal, a centralidade da Bíblia, a liturgia em vernáculo, a renovação da práxis eclesial e o contato com os protestantes via Conselho de Genebra.

O anúncio do novo Concílio provocou ainda reações positivas da parte dos cristãos não-católicos. O Conselho de Genebra demonstrou imediatamente pronto interesse em acompanhar os desdobramentos do Concílio no tocante às questões ecumênicas. Em fins de março vêm a Roma o representante de Constantinopla Iakovos de Malta em nome do Patriarca Atenágoras. Os anglicanos enviaram ao Papa um representante portando carta do Arcebispo de Cantuária. Ainda que sabedores dos obstáculos reais do diálogo ecumênico, as lideranças cristãs europeias receberam o anúncio do Concílio como um momento histórico inédito 
que abria uma nova era de relacionamento com a Igreja de Roma.

Não faltaram ainda reações da parte da diplomacia e da imprensa. Criou-se, de fato, uma grande expectativa sobre o significado e os objetivos do evento. O tom predominante foi o ecumênico. Muitos cogitam se se trataria de um Concílio para todos os cristãos. Pode-se dizer que a sociedade, da parte de crentes e não crentes, entendeu a importância renovadora do evento para aquele momento histórico. $\mathrm{O}$ anúncio do Concilio plantou, de fato, a "flor de inesperada primavera" para além dos muros do Vaticano e dos limites das hierarquias, fazendo-a germinar como coisa grande, senão como coisa pública (ALBERIGO, 1996, p. 40-48). O fato é que a personalidade roncallina propiciou um percurso de agregação em prol da renovação que parece ter acordado a consciência eclesial sobre a necessidade de rever a si mesma, na sua identidade e na sua relação com o mundo de então. Com seu modo espontâneo e audacioso de conduzir as coisas havia lançado a proposta da maior assembleia da história (O’MALLEY, 2014, p. 30).

\section{A autocompreensão do Concílio}

A pergunta inicial feita por muitos se o novo Concílio seria a continuação/conclusão do Vaticano I foi respondida quando João XXIII comunicou ao Cardeal Tardini em 14 de julho que o Concílio se chamaria Vaticano II. Os concílios anteriores estiveram relacionados a crises. Naquele momento não havia nenhuma crise que perturbasse a estabilidade da Barca de Pedro, a não ser a crise do mundo moderno recém-saído da grande guerra, em clima tenso de guerra fria e em acelerado processo de desenvolvimento científico e tecnológico, com impactos diretos sobre a tradição cristã. Então para que um Concílio? A ideia estava associada a objetivos positivos, a uma intencionalidade de renovação da Igreja e do mundo. A data de 25 de janeiro foi escolhida para o anúncio, por estar encerrando a semana de orações pela unidade Cristã. A alma do pastor das fronteiras religiosas ansiava pela unidade. Durante seu ministério episcopal convivera por longos anos nos limites do catolicismo, seja na relação com outros 
cristãos na Bulgária e na Turquia-Grécia, seja no celeiro do pensamento e da cultura moderna secularizada em Paris. A Igreja deveria rever a si mesma para se apresentar ao mundo como esposa fiel de Cristo e servidora da humanidade (O’MALLEY, 2014, p. 30). Tratava-se de um Concílio novo, destinado a colocar a Igreja em diálogo com o mundo e para tanto deveria revigorar sua imagem segundo o que pensou o próprio Jesus Cristo. A positividade do novo Concílio nascia como graça para a Igreja e para o próprio mundo. João XXIII escreve em seu diário, em 15 de setembro de 1962, um Resumo sobre as grandes graças feitas a quem tem pouca estima por si próprio. A primeira graça é o Pontificado, acolhido como serviço sem jamais desejá-lo. A segunda graça diz respeito ao surgimento espontâneo de algumas ideias em seu espírito, “ideias, nada complexas, pelo contrário bastante simples, mas de vasto alcance e responsabilidade em relação ao futuro, e com sucesso imediato”. Dentre essas ideias inspiradas inclui o Concilio: "O primeiro a ficar surpreendido com esta com esta minha proposta fui eu próprio, sem que ninguém alguma vez me tivesse dado indicações a este respeito. E dizer que tudo, depois, me pareceu tão natural no seu imediato e natural desenrolar!" (Diário íntimo, p. 366). O sentido da expressão tão repetida "flor de inesperada primavera", utilizada para explicar a origem da ideia do Concílio, fica esclarecido nessa espontaneidade espiritual do Bom Papa. Diz ainda em seu Diário que

das várias iniciativas de caráter pastoral [...] tudo me veio da absoluta, tranqüila, amorosa, direi até silenciosa, inspiração do Senhor a este seu pobre servo que, sem nenhum mérito da sua parte [...] pôde ser um instrumento não de todo inútil em honra de Jesus, e de edificação para muitas almas. (JOÃO XXIII, 1964, p. 366 - Diário íntimo, 14 de agosto de 1961,).

Assim entende todas as suas ações e

agora o vastíssimo movimento, de proporções imprevistas e imponentíssimas, do Concilio Ecumênico: tudo confirma a bondade do princípio de esperar e de exprimir com fé, com modéstia, com fervor confiante, as boas inspirações da graça de Jesus, que preside ao governo do mundo e o conduz às mais altas finalidades da criação, da redenção, da glorificação final e eterna das almas e dos povos. (JOÃO XXIII, 1964, p. 366 - Diário íntimo, 14 de agosto de 1961). 
Essa convicção íntima de que o Concílio nasceu de inspiração divina é também externada oficialmente pelo Papa: "Consideramos inspiração do Altíssimo a ideia de convocar um Concilio Ecumênico, que desde o inicio de Nosso Pontificado se apresentou à nossa mente, como flor de inesperada primavera" (JOÃO XXIII, Superno Dei Nutu de 5 de maio de 1959). Em alocução de 13 de novembro de 1960 na Basílica de São Pedro explicita que "a obra do próximo concilio Ecumênico e, verdadeiramente, concebida toda para restituir o seu esplendor, no semblante da Igreja de Cristo, aos traços mais simples e mais puros de suas origens, a fim de apresentá-la como seu divino fundador a criou” (ALBERIGO, 2000, p. 173). Além da firme convicção de fé sobre o significado inspirado do Concílio e de seu objetivo eclesial, o Papa reitera seu entusiasmo em relação ao evento; vislumbra nele um grande evento que poderá mostrar a Igreja ao mundo. Ao lançar o Regulamento do Concílio pelo Motu proprio de 6 de agosto de 1962 afirma em tom laudatório que chega a destoar do texto normativo que encabeça:

Aproximando-se o Concílio Ecumênico Vaticano II, Nossa alma enche-se de grande alegria ao pensamento grandioso espetáculo que em breve apresentará a imensa multidão dos Bispos, reunidos em Roma, vindos de todas as partes do mundo, afim de tratarem conosco [...] dos mais graves problemas da Igreja [...]. (JOÃO XXIII, 1962).

Afirma ainda a proteção de Deus sobre os trabalhos realizados: "Por isso oferecemos a Deus as mais profundas ações de graças, não só por nos haver inspirado a ideia de empreendermos obra tão importante, mas ainda por haver constante e eficacissimamente guiado os trabalhos preparatórios do Concílio. Essa assistência confirma grandemente a Nossa confiança em que os socorros sobrenaturais que foram prodigalizados desde o início deste empreendimento continuarão a ser abundantes e levarmos a bom termos" (KLOPPENBURG, 1963, p. 271). E reafirma os três objetivos do Concílio: a verdade, a unidade e a paz. 


\section{Do Anúncio à organização}

O carisma inicial eclodido no primeiro anúncio foi sendo ordenado passo a passo, sob a condução entusiasta e firme do Pontífice. Na medida em que foi fazendo suas declarações e publicando Documentos é que os objetivos e o formato do novo Concílio foram, de fato, tornando-se claros. Em 17 de maio, festa de Pentecostes, foi nomeada a Comissão antepreparatória presidida pelo Secretário de Estado Cardeal D. Tardini, sendo composta por bispos e padres prevalentemente italianos. A essa Comissão competia elaborar material de consulta aos bispos de todo o mundo, catalogar as respostas obtidas em relatórios a partir dos quais os Dicastérios da Cúria Romana pudessem apresentar propostas para o Concílio. Nessa fase já se verifica com toda clareza o que Berger e Luckmann explicam como terceira fase da construção da legitimação: "que contém teorias explícitas pelas quais um setor institucional é legitimado em termos de um corpo diferenciado de conhecimentos [...] oferecem quadros de referências bastante amplos para os respectivos setores da conduta institucionalizada" (1985, p. 130). O Vaticano vai sendo formatado e sendo oferecido ao conhecimento de todos, como um fato legitimo da instituição católica:

a) Os três focos. Em sua primeira Encíclica, Ad Petri Cathedram, de 29 de junho de 1959, João XXIII apresentava como objetivos gerais do Concílio promover a verdade, a unidade e a paz (n. 1 e 2) e estabelecia o local de realização do evento: a Basílica de São Pedro. Na mesma Encíclica afirma que

sem dúvida o Concilio constituirá maravilhoso espetáculo de verdade, unidade e caridade; espetáculo que ao ser contemplado pelos que vivem separados desta Sé Apostólica, os convidará, como esperamos, a buscar e conseguir a unidade pela qual Cristo dirigiu ao Pai do Céu a sua fervorosa oração (JOÃO XXIII, 1959, n. 33).

$\mathrm{Na}$ festa de pentecostes, de 05 de junho de 1960, dois documentos são dignos de nota em termos de esclarecimento sobre o futuro Concílio. O primeiro é o Motu Proprio Superno Dei Nutu, que institui as Comissões Preconciliares, 
concluindo, assim, a fase antepreparatória. O segundo é a Alocução feita na Basílica de São Pedro, onde são explicitadas as fases e metas do evento conciliar.

b) As Comissões. No Motu proprio institui dez Comissões preparatórias com suas composições e funcionamento, o Secretariado de comunicação, Secretariado para os não-cristãos e Comissão central.

c) As fases. Na Alocução o papa prevê com clareza quatro tempos:

1) Uma introdução, ou tomada de posição, antepreparatória e geral: a que até aqui foi feita; 2) uma introdução preparatória propriamente dita: a que agora se anuncia; 3) a celebração da augusta e geral reunião; 4) enfim: a promulgação dos Acta Concilii, isto é, de tudo o que se conveio em verificar, declarar e propor [...]. (KLOPPENBURG, 1962, p. 42).

As muitas Alocuções feitas pelo Papa vão deixando sempre mais claros os objetivos e a própria dinâmica do Concílio. Com cuidado de pastor conduz a preparação dos trabalhos com firme propósito e com delicada estratégia política. A condução da preparação não foi atribuída ao Santo Ofício.

d) A renovação. No discurso às Comissões Preparatórias, em $14 \mathrm{de}$ setembro de 1960, demarca a posição fundamental do Concílio, afirmando que os Concilio do passado responderam, sobretudo

a diversas e importantes preocupações de exatidão doutrinária sobre a lex credendi à medida que as heresias e os erros tentavam penetrar na Igreja [...] nesta época moderna, pois, mais que de tal ou tal ponto de doutrina ou de disciplina, que seria necessário reconduzir às fontes puras da Revelação e da Tradição, será necessário recolocar em seu devido valor e resplendor a própria substância do pensamento e da vida humana e cristã, da qual a Igreja é depositária e mestra através dos séculos. (KLOPPENBURG, 1962, p. 17-18).

e) Sintonia com a época. Os Documentos oficiais continuam sinalizando para as finalidades do grande Sínodo. A Bula de Indicção do Concilio (Constituição Apostólica Humanae Salutis), promulgada solenemente no natal de 1961, ressalta a 
necessidade de colocar a Igreja serviço do mundo moderno, marcado pela ambiguidade do progresso em todas as esferas. Após constatar a grave crise pela qual passa a sociedade, afirmar a necessidade de distinguir na mesma os "sinais dos tempos", aponta para a responsabilidade da Igreja nos tempos atuais: "Nós, desde quando subimos ao Supremo Pontificado, não obstante nossa indignidade e por um desígnio da Providência, sentimos logo o urgente dever de conclamar os Nossos filhos para dar à Igreja a possibilidade de contribuir mais eficazmente na solução dos problemas da idade moderna”. A Igreja que

sente o ritmo do tempo e que em cada século, se orna de um novo esplendor, irradia novas luzes, realiza novas conquistas, permanecendo sempre idêntica a si mesma, fiel à imagem divina impressa em sua face pelo Esposo que a ama e protege, Jesus Cristo (KLOPPENBURG, 1962, p. 85-86).

f) A busca da justiça. Na Carta Apostólica Oecumenicum Concilium, de 28 de abril de 1962, acrescenta uma finalidade social ao Concilio.

Apagamos a luz dos céus tanto negando a Deus como suprimindo directe vel indirecte nosso próprio irmão, ou desconhecendo os direitos inalienáveis da sua natureza de pessoa livre da sua vocação cristã. A expectativa do Concílio Ecumênico exige, pois, um mais decidido esforço de justiça individual e social e um empenho mais generoso de caridade, um dom jubiloso de si mesmo para o bem comum, a fim de que uma ordem mais eqüitativa nas relações familiares, sociais e internacionais possa progredir, para a vantagem de toda a humanidade. (KLOPPENBURG, 1962, p. 101).

Estava lançado assim o projeto da grande assembleia que se desdobraria em três fases (Antepreparação, Preparação e Realização) e se realizaria em quatro Sessões no percurso de quatro anos. De fato, o anúncio do Vaticano II, no modo pessoal e no tom espiritual como foi feito e nos moldes pedagógicos e metodológicos em que foi sendo explicitado, construiu um novo modelo de Concilio (THEOBALD, 2015, p. 39) e instaurou um caminho novo para os trabalhos conciliares. O carisma do bondoso Papa (PASSOS, 2013, p. 33-45) persistiu como motivação e rumo para os padres conciliares após sua partida na festa de Pentecostes de 3 de junho de 1963. E o novo pentecostes da Igreja, como desejara 
ser o Concílio, se fez fato, na medida em que sob a direção de Paulo VI exigiu da Igreja tomada de consciência de si mesma e busca de diálogo com o mundo. O Vaticano II nasceu em sua essência do anúncio primeiro entoado com entusiasmo e medo por João XXIII.

A concepção do Concilio foi construída aos poucos pelo Papa e confirmada por aqueles que recepcionavam o projeto. De intuição subjetiva o concilio foi sendo objetivamente construído e, por conseguinte, adquirindo legitimidade como evento institucional (BERGER, 2003, p. 42-45). Não se pode esquecer nesse período o apoio de alguns que não somente aderem ao projeto, mas passam a contribuir com a própria concepção e preparação do grande evento. Dentre esses se destaca a figura do Cardeal Agostinho Bea, intelectual de grande envergadura nomeado para dirigir o Secretariado para a União dos Cristãos (ZAMAGNA, 2015, p. 53-54).

Três circularidades subjacentes ou, ás vezes explícitas, podem ser detectadas nessa fase como movimento colocados em ação e que encontrarão no processo conciliar os meios de efetivação e de formulação do pretendido aggiornamento: entre a Igreja e a sociedade, entre a doutrina e os tempos modernos e entre a Igreja e os demais cristãos. Essas circularidades serão aprofundadas e ampliadas durante o processo conciliar. A relação da Igreja com a sociedade chegará à autonomia moderna, a relação com o pensamento moderno dialogará com as ciências e a relação com os demais cristãos atingirão a esfera do diálogo com outras religiões. Nesse sentido, o processo de legitimação da renovação atinge durante a realização do Concilio seu ponto máximo como um novo "universo simbólico" que possibilitou a integração dos sujeitos eclesiais nas novas referências incorporadas à tradição católica. O desenrolar do processo conduzido por João XXIII criou socialmente a ideia de um evento que ligava a sua novidade com a tradição anterior e se mostrava politicamente viável e, nos termos utilizados por Hobsbawm, inventava-se uma nova tradição (HOBSBAWM, 2002, p. 13). Nascia assim o Vaticano II da Igreja e a Igreja do Vaticano II. 


\section{Conclusão: o desabrochar da flor}

A "flor de inesperada primavera" desabrochou e produziu frutos. O seu progenitor construiu sua legitimidade dentro da longa tradição consolidada e da pesada instituição católica. Da inspiração inicial sem muita definição, passou à conceituação e foi concluído como um sistema completo de conceitos e de valores bem expressos nas palavras e nos atos do Papa renovador. Entre 29 de Janeiro de 1959 e 11 de outubro de 1962 o novo Concílio foi construído e se apresentou como evento plausível e espetacular. O aggiornamento foi legitimado dentro de uma tradição que o havia dispensado na década anterior como perigo à verdade e ameaça a estabilidade institucional do catolicismo. Em termos sociológicos, concluiu-se o processo de construção de uma tradição que se incorpora à anterior e que integra em seu significado todos os significados menores. De fato, agora nesse universo simbólico (Vaticano II) "todos os setores da ordem institucional acham-se integrados num quadro de referência global, que constituiu, então, um universo no sentido literal da palavra, porque toda a experiência humana pode agora ser concebida como se efetuando no interior dele" (BERGER \& LUCKMANN, 1985, p. 131-132).

O discurso de Abertura do Concílio expressa a conclusão da construção de sua ideia por parte de João XXIII. Ali se pode constatar uma teoria do grande evento, um sistema simbólico que articula a gênese, a estrutura e a função do novo Concílio nas palavras solenes e autorizadas do Papa. O novo estava legitimamente apresentado aos padres conciliares na forma de uma peça teológica “indispensável substrato sobre o qual mais tarde poderão ser construídos os edifícios da legitimação” (BERGER, 2003, p. 67) durante as sessões conciliares. A demonstração da integração dos padres a esse "universo simbólico" pode ser verificada já na primeira Sessão quando são rejeitadas as estratégias da instituição curial que pretendia sustentar as velhas práticas de controle da Igreja. O processo conciliar fez concessões com a tradição, porém adotou o aggiornamento como meta e caminho das discussões e das decisões. 
Essa construção não significou, entretanto, uma construção definitiva do que deveria ser o novo Concílio e que, de fato, ele foi, mas um quadro completo que permitiu articular a longa tradição com a tradição nova, a integração dos sujeitos diversos em torno de significados comuns e, desde então, a transmissão da doutrina conciliar como parte integrante da longa tradição católica.

\section{REFERÊNCIAS}

ALBERIGO, G . Breve história do Concilio Vaticano II. Aparecida: Santuário, 2006.

ALBERIGO, G. Ângelo José Roncalli: João XXIII. São Paulo: Paulinas, 2000.

ALBERIGO, G. (Dir.) História do Concilio Vaticano II. Vol. I. Petrópolis: Vozes, 1996. BERGER, P. \& LUCKMANN, T. A construção social da realidade. Petrópolis: Vozes, 1985 .

BERGER, Peter L. O dossel sagrado; elementos para uma sociologia da religião. São Paulo: Paulus, 2003.

DENZINGER-HÜNERMANN. Compêndio dos símbolos, definições e declarações de fé e moral. São Paulo: Paulinas/Loyola, 2007.

HOBSBAWM, Eric - RANGER, Terence. A invenção das tradições. São Paulo: Paz e Terra, 2002.

JOÃO XXIII. Carta Apostólica Superno Dei Nutu. 5 de maio de 1959. Disponível em: $<$ https://w2.vatican.va/content/john-xxiii/es/apost_letters/196o/documents/hf_jxxiii_apl_19600605_superno-dei.html >. Acesso em: 25 de janeiro de 2016.

JOÃO XXIII. Carta Apostólica Aproppinquante Concilio. o6 de agosto de 1962. Disponível em: <https://w2.vatican.va/content/johnxxiii/es/motu_proprio/documents/hf_j-xxiii_motu-proprio_19620806_appropinquanteconcilio.html>. Acesso em 26 jan. 2016.

JOÃO XXIII. Diário íntimo. Rio de Janeiro: Agir, 1964.

JOÃO XXIII. Encíclica Ad Petri Cathedram. Disponível em:

<https://w2.vatican.va/content/john-xxiii/pt/encyclicals/documents/hf_jxxiii_enc_29061959_ad-petri.html>. Acesso em: 25 de janeiro de 2016.

KLOPPENBURG, B. Concilio Vaticano II. v. I. Petrópolis: Vozes, 1962.

KLOPPENBURG, B. Concilio Vaticano II. v. II. Petrópolis: Vozes, 1963. 
O’MALLEY, O que aconteceu no Vaticano II. São Paulo: Loyola, 2014.

PASSOS, J. Décio. Concílio Vaticano II; reflexões sobre um carisma em curso. São Paulo: Paulus, 2014.

THEOBALD, Christoph. A recepção do Concilio Vaticano II., v. I. São Leopoldo: Unisinos, 2015.

WEBER, M. Economia y sociedad. México: Fondo de Cultura Económica, 2007.

ZAMAGNA, Domingos. Verbete Bea, Agostinho. In PASSOS, J. D. \& SANCHEZ, W. L (Coord.) Dicionário do Concílio Vaticano II. São Paulo: Paulus/Paulinas, 2015. 